\title{
Correlated Electrophysiology and Morphology of the Ependyma in Rat Hypothalamus
}

\author{
C. R. Jarvis ${ }^{a}$ and R. D. Andrew \\ Department of Anatomy, Queen's University, Kingston, Ontario, Canada K7L 3N6
}

The ependyma lines the ventricular system of the vertebrate brain and spinal cord. Although its embryology and morphology have been studied extensively, little is known of its physiological properties, particularly in mammals. Tanycytes are modified ependymal cells that are found predominantly lining the floor of the third ventricle, overlying the median eminence. Their processes accompany and enwrap neuroendocrine axons that course from hypothalamic nuclei to terminals in the median eminence, but the significance of this interaction is not yet understood. Intracellular recording and injection techniques were used to study ependymal cells and tanycytes of the rat in the hypothalamic slice preparation after differentiating their respective regions morphologically. With extracellular $\left[\mathrm{K}^{+}\right]=6.24 \mathrm{~mm}$, the mean membrane potential $( \pm S D)$ for common ependyma was $-79.9 \pm 1.40 \mathrm{mV}$ and for tanycytes, $-79.5 \pm 1.77 \mathrm{mV}$. Input resistances $\left(R_{\text {in }}\right)$ were very low $(\ll 1 \mathrm{M} \Omega$ ). Single-cell injection of Lucifer yellow revealed dye coupling among 2-70 ependymal cells and 5-48 tanycytes. In both freeze-fractured replicas and thin sections, large numbers of gap junctions were found between adjacent ependymal cells and between adjacent tanycytes. The observations of numerous gap junctions, extensive dye coupling and low input resistance demonstrated that both populations are strongly coupled networks. Perhaps for this reason, attempts to uncouple these cells using sodium propionate or $\mathrm{CO}_{2}$ were unsuccessful. Electrical stimulation of the arcuate nucleus did not elicit any detectable synaptic response in impaled tanycytes, so that the functional significance of synaptoid contacts between neuroendocrine neurons and the postsynaptic tanycytes is not yet apparent. Ependymal cells and tanycytes demonstrated a near-Nernstian response to changes in extracellular [ $\left.\mathrm{K}^{+}\right]$ between 3 and $20 \mathrm{~mm}$. This finding, as well as their high negative resting potential, low $\boldsymbol{R}_{\text {in, }}$ extensive coupling and absence of spontaneous electrical excitability demonstrate that ependymal cells possess numerous glial characteristics

\footnotetext{
Reccivcd July 8, 1987; revised Feb. 8, 1988; accepted Feb. 15, 1988.

We thank Dr. R. R. Shivers, University of Western Ontario, for use of his freeze-fracture facilities. Also thanks to Dr. P. K. Rose for helpful discussion, Dr. B. R. Ransom for supplying a manuscript in press, Ms. A. Doyle for typing the manuscript, and Mr. H. Verstappen for photographic work. Supported by operating and equipment grants from the Canadian MRC, the Botterell Foundation, and the Dean's MRC Fund.

Correspondence should be addressed to Dr. R. David Andrew at the above address.

a Present address: Division of Neurology, Montreal General Hospital, 1650 Cedar Avenue, Montreal, Quebec H3G 1A4 Canada.

Copyright (C) 1988 Society for Neuroscience $0270-6474 / 88 / 103691-12 \$ 02.00 / 0$
}

and may therefore have similar functions. In the hypothalamus, ependyma probably take up $K^{+}$released from adjacent endocrine neurons and shunt it to the ventricular space.

The ventricular system of the brain and spinal cord is lined by the ependyma, a single layer of squamous, cuboidal, or columnar epithelial cells. Some ependymal cells, termed tanycytes, have long basal processes extending into the underlying neuropil. Tanycytes form the ependymal lining over the circumventricular organs and are found scattered within the ependymal layer of the ventricles and spinal canal. Most cells lining the third ventricle are cuboidal (common ependyma), although tanycytes are clustered along the lateroventral wall and in the floor overlying the median eminence. Tanycyte processes accompany and enwrap neuroendocrine axons that course from hypothalamic nuclei to terminate on the portal vasculature of the median eminence (Kozlowski and Coates, 1985). Ultrastructurally, some neuroendocrine axons appear presynaptic to tanycyte processes (Card and Moore, 1985), but the significance of this interaction is not yet understood.

Although the morphology of common ependymal cells and tanycytes has been thoroughly examined (reviewed by Kobayashi et al., 1970; Fleischhauer, 1972; Peters et al., 1976; Bruni et al., 1985; Flament-Durand and Brion, 1985), the function of these cells remains unknown. Common ependyma may play a role in the absorption/secretion of CSF (review by Bruni et al., 1985), and the beating of their apical cilia is thought to produce movement of the CSF (Scott et al., 1974). Although it is unlikely that bulk fluid movement results, such beating could stir the fluid at the CSF-ependyma interface, hastening the exchange of substances. Several functions have been attributed to tanycytes (review by Peters et al., 1976; Bruni et al., 1985; FlamentDurand and Brion, 1985), including phagocytosis (Brawer and Walsh, 1982), mechanical support, regulation of extracellular space constituents, and transport of substances between CSF and the portal vasculature (critical review by Pilgrim, 1978). These functional hypotheses are based largely on morphological observations. Of particular interest is the intimate structural relationship between the ependyma of the third ventricle and neuroendocrine neurons of the hypothalamus (Card and Moore, 1985; Kozlowski and Coates, 1985).

In contrast to the numerous structural studies, electrophysiological data are restricted to 2 studies examining the properties of ependyma in the turtle (Chan and Nicholson, 1986; Connors and Ransom, 1987), and one study examining mammalian ependymal cells in culture (Hild et al., 1965). In the present study, we intracellularly recorded and dye-injected 2 morphologically distinct populations of ependymal cells (cu- 


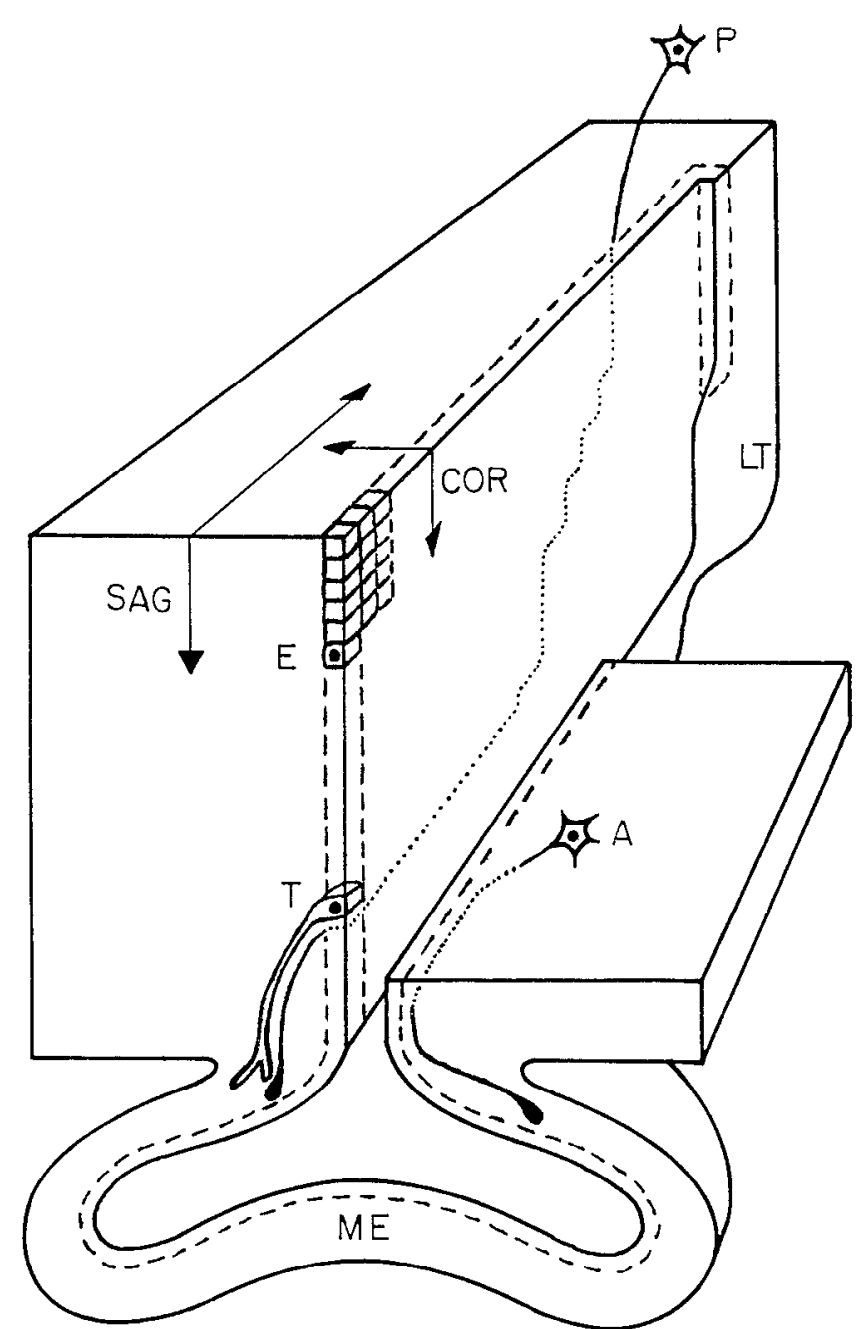

Figure 1. Diagram of the rat hypothalamus viewed from a caudal aspect. Slices of the hypothalamus $(350-500 \mu \mathrm{m})$ were cut in a coronal $(C O R)$ or sagittal $(S A G)$ plane and ependyma impaled with microelectrodes. $E$, common ependymal cell; $T$, tanycyte; $L T$, lamina terminalis; $P$, endocrine neurons of preoptic area; $A$, endocrine neurons of arcuate nucleus. Note the close association (1) between common ependyma and neuroendocrine axons and (2) between tanycyte processes, neuroendocrine axons, and the capillaries of median eminence $(M E)$ into which neurohormone is secreted. (Adapted from Kozlowski and Coates, 1985.)

boidal cells and tanycytes) to better understand their function. Some of the results have been presented in preliminary form (Jarvis and Andrew, 1987).

\section{Materials and Methods}

\section{Brain dissection}

Male Sprague-Dawley rats ( $70-300 \mathrm{gm})$ were decapitated and the dome of the cranium removed. The cranial nerves were cut, while the base of the brain was progressively exposed by gently lifting the pontine area with a small spatula. The hypothalamus was blocked with a razorblade by cutting parasagittally lateral to the circle of Willis and horizontally $1-2 \mathrm{~mm}$ above the anterior commissure. A coronal cut was made anterior to the optic chiasma at the level of the anterior commissure, and the tissue block was then further processed for morphological or electrophysiological studies.

\section{Morphology}

Transmission electron microscopy (TFM). Slices $(500 \mu \mathrm{m})$ from blocked hypothalamus were placed in oxygenated saline solution and fixed at $4^{\circ} \mathrm{C}$ for $2 \mathrm{hr}$ in a modified Karnovsky's fixative (pH 7.2-7.4) of $1.5 \%$ paraformaldehyde and $0.7 \%$ glutaraldchyde in $0.1 \mathrm{~m}$ sodium cacodylatc. Washing in $0.1 \mathrm{~m}$ sodium cacodylate buffer preceded postfixation in $1 \%$ buffered osmium tetroxide for $1.5 \mathrm{hr}$. Following rinsing in buffer, the tissue was stained en bloc in $1 \%$ uranyl acetate overnight and dehydrated through an ethanol series. Using propylenc oxide as a transition solvent, the slices were embedded in 100\% Epon in Beam capsules and polymerized at $16^{\circ} \mathrm{C}$ for $1-2 \mathrm{~d}$.

Semithin $(0.7 \mu \mathrm{m})$ and ultrathin $(70 \mathrm{~nm})$ sections were cut with an ultramicrotome. For light microscopy, semithin sections were mounted on slides, stained with toluidine blue and photographed with a Zeiss Photomicroscope II. For TEM, silver sections were mounted on copper grids, stained with $3 \%$ uranyl acetate followed by $2 \%$ lead citrate and examined with a Hitachi 500 TEM at $75 \mathrm{kV}$.

Scanning electron microscopy (SEM). The hypothalamus was blocked, and the dorsal extent of the third ventricle was cut. The adjacent halves of the hypothalamus were gently spread apart and pinned down in a dissecting tray. This exposed the entire ependymal lining of the third ventricle, the walls of the third ventricle remaining attached by the floor. Following fixation as for TEM (above), the tissue was washed in $0.1 \mathrm{M}$ sodium cacodylate buffer, dehydrated through an ethanol series and transferred to Freon-113. Using a Polaron critical-point dryer, the tissue was dried with liquid $\mathrm{CO}_{2}$ at $38^{\circ} \mathrm{C}$ and 1200 psi. The blocks were coated with gold in an argon-pure vacuum atmosphere using a Polaron sputter coater set at $15 \mathrm{~mA}$ and $2.3 \mathrm{kV}$, for $3 \mathrm{~min}$. The specimens were examined with a Hitachi S450 SEM fitted with a Polaroid camera.

Freeze fracturing. The hypothalamus was blocked and sliced coronally $(1 \mathrm{~mm})$. The tissue was fixed at $4^{\circ} \mathrm{C}$ for $1 \mathrm{hr}$ in a cacodylate-buffered solution of $1 \%$ paraformaldehyde and $1 \%$ glutaraldehyde $(\mathrm{pH} 7.2-7.4)$ and then washed in $0.1 \mathrm{M}$ cacodylate buffer containing $4 \%$ glucose ( $w \mathrm{l}$ ) vol). Blocks cryoprotected in $30 \%$ glycerol were placed on gold specimen supports (Balzers) and oriented to fracture in the coronal plane. The specimens were immersed in Freon-22 (maintained near its freezing point by liquid $\mathrm{N}_{2}$ ) and stored in liquid $\mathrm{N}_{2}$. Tissue was fractured in a Balzers BAF 301 Freeze-Etching Unit (Shivers and Brightman, 1976) while the stage was maintained at $-115^{\circ} \mathrm{C}$ and the vacuum at $10^{-6} \mathrm{Torr}$. The specimens were coated with platinum $(2300 \mathrm{~V}$ and $70 \mathrm{~mA}$ at 400 $\mathrm{Hz}$ for 6-8 sec) followed by carbon $(2500 \mathrm{~V}$ and $110 \mathrm{~mA}$ at $400 \mathrm{~Hz}$ for $4-8 \mathrm{sec}$ ). Tissue adhering to the replicas was removed in filtered $10 \%$ household bleach. The replicas were rinsed and collected on copper grids and examined with TEM.

\section{Electrophysiology}

Tissue preparation. The hypothalamus was blocked as described above and placed ventral side down on a tissue slicer. Beginning at the anterior commissure, coronal slices were cut (Fig. 1) and placed in a recording chamber. Slice dimensions were approximately $3-4 \mathrm{~mm} \times 5 \mathrm{~mm} \times$ $350-500 \mu \mathrm{m}$ thick (sce Fig. $3 A$ ). Alternately, 2 sagittal slices were prepared by cutting the roof of the third ventricle so that the opposing halves of the hypothalamus could be pulled apart. The ventricular floor was then cut to separate the halves. With the ependymal layer exposed, each half of the block was sliced approximately $500 \mu \mathrm{m}$ parasagittal to the midline (Fig. 1) using the tissue slicer.

Slices were weighted with $0.38-\mathrm{mm}$-diameter silver wire and superfused with artificial CSF consisting of (in mM): $124 \mathrm{NaCl}, 25 \mathrm{NaHCO}_{3}$, $5 \mathrm{KCl}, 1.3 \mathrm{MgSO}_{4}, 1.24 \mathrm{KH}_{2} \mathrm{PO}_{4}, 2.4 \mathrm{CaCl}_{2}$, and 11 glucose. A peristaltic pump delivered the saline through a thermostatically heated water bath $\left(36 \pm 1{ }^{\circ} \mathrm{C}\right)$ at a flow rate of $0.2-0.5 \mathrm{ml} / \mathrm{min}$. Both the perfusate and the chamber were saturated with $95 \% \mathrm{O}_{2} 5 \% \mathrm{CO}$. The tissue, which incubated at least $1 \mathrm{hr}$ before recording, was transilluminated from below with a fiberoptic light source and was viewed with a dissecting microscope.

Intracellular recording. Intracellular microelectrodes were pulled using either a Haer or a Brown-Flaming micropipette puller. The micropipettes were filled with either $3 \mathrm{M} \mathrm{KCl}$ or $3 \mathrm{M} \mathrm{K}$-acetate (25-100 M 2 ) and connected to the electrometer (WPI model S-7071) by an acrylic half-cell microelectrode holder coupled to a miniature probe. The probe was mounted on a 3-dimensional hydraulic micromanipulator, which was used to position and advance the microelectrode through the slice. A calibrator connected between the ground and the bath electrode generated a $10 \mathrm{mV}, 5 \mathrm{msec}$ pulse. In coronal slices the ependyma could be visualized as a clear layer lining the third ventricle, which facilitated electrode placement. Single-cell impalements were obtained by activating a "tickler" switch on the intracellular amplifier while advancing the microelectrode through the slice in $1-4 \mu \mathrm{m}$ steps. Recordings were 

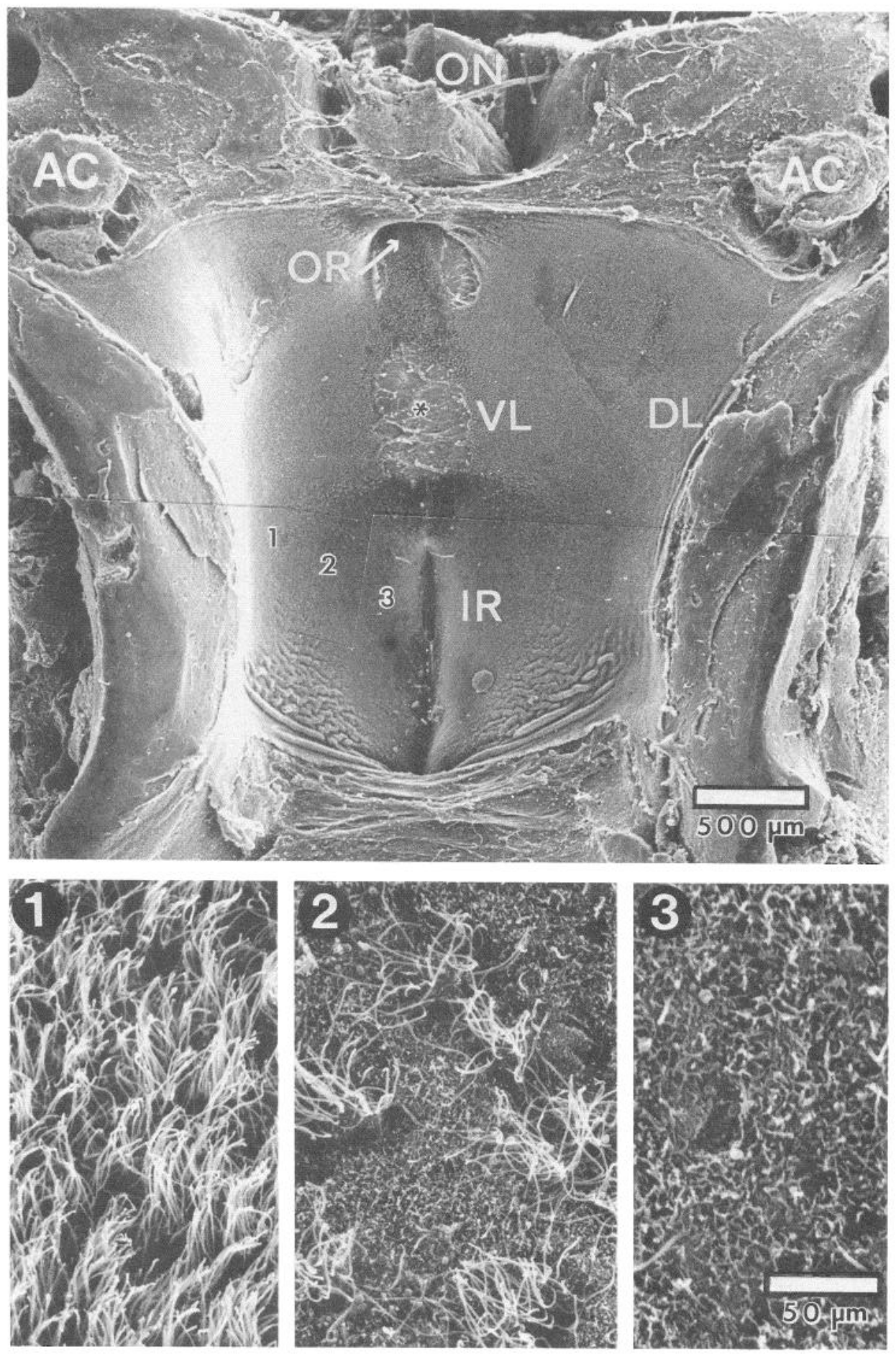

Figure 2. Collage of 4 scanning micrographs showing the floor (medially) and lateral walls of the third ventricle. Areas 1-3 are shown at higher magnification below. Area 1 in the dorsolateral wall $(D L)$ contains only ciliated cells (common ependyma). Area 3 in the infundibular recess $(I R)$ contains only nonciliated cells with microvillar extensions (tanycytes). Area 2 is a transitional zone containing both cell types. $A C$, anterior commissure cut at midline; $O N$, optic nerves; $O R$, optic recess; $V L$, ventrolateral wall. stored on a 4-channel FM instrumentation recorder. Data were played onto a storage oscilloscope screen or chart recorder and photographed.

The resting membrane potential $\left(V_{m}\right)$ was recorded from a stable impalement as based on the following criteria: (1) penetration of the cell membrane was accompanied by a sharp deflection of more than $-76 \mathrm{mV}$; (2) the resting $V_{m}$ was maintained for $>5 \mathrm{~min}$; and (3) the potential reading returned to the $0 \mathrm{mV}$ reference level upon withdrawal from the cell. Measurement of cell input resistance $\left(R_{\mathrm{in}}\right)$ was attempted with $3 \mathrm{M} \mathrm{KCl}$-filled microelectrodes (30-80 M $)$ ). A current pulse (1-8 $\mathrm{nA}$ ) was injected into the cell and the resulting voltage change measured. The bridge was balanced during current injection to counteract changes in electrode resistance. To assess the relationship between extracellular $\mathrm{K}^{+}$and $V_{m}$, the extracellular $\mathrm{K}^{+}$concentration $\left(\left[\mathrm{K}^{+}\right]_{\mathrm{o}}\right)$ was altered over several minutes (range, $0-18.72 \mathrm{~mm}$ ). Isosmolality was maintained by substituting $\mathrm{KCl}$ and $\mathrm{NaCl}$.

Stimulation of arcuate neurons. Ultrastructural profiles that may represent chemical synapses between arcuate neurons and postsynaptic tanycytes have been observed (Card and Moore, 1985). To determine if such synapses could be detected electrophysiologically, the arcuate nucleus was stimulated with a concentric bipolar electrode in an attempt to elicit synaptic responses in impaled tanycytes. Stimulating pulses (1$15 \mathrm{~mA}, 0.2 \mathrm{msec}$ ) were delivered at $1 \mathrm{~Hz}$ for $1-5 \mathrm{sec}$.

Dye injections. The fluorescent dye Lucifer yellow (MW $=457 \mathrm{Da})$ was used to study dye coupling among cells, as it is small enough to pass through gap junctions. Micropipettes were filled with $5 \%$ Lucifer yellow in $0.33 \mathrm{~m}$ lithium citrate (Stewart, 1978). Electrode resistances 


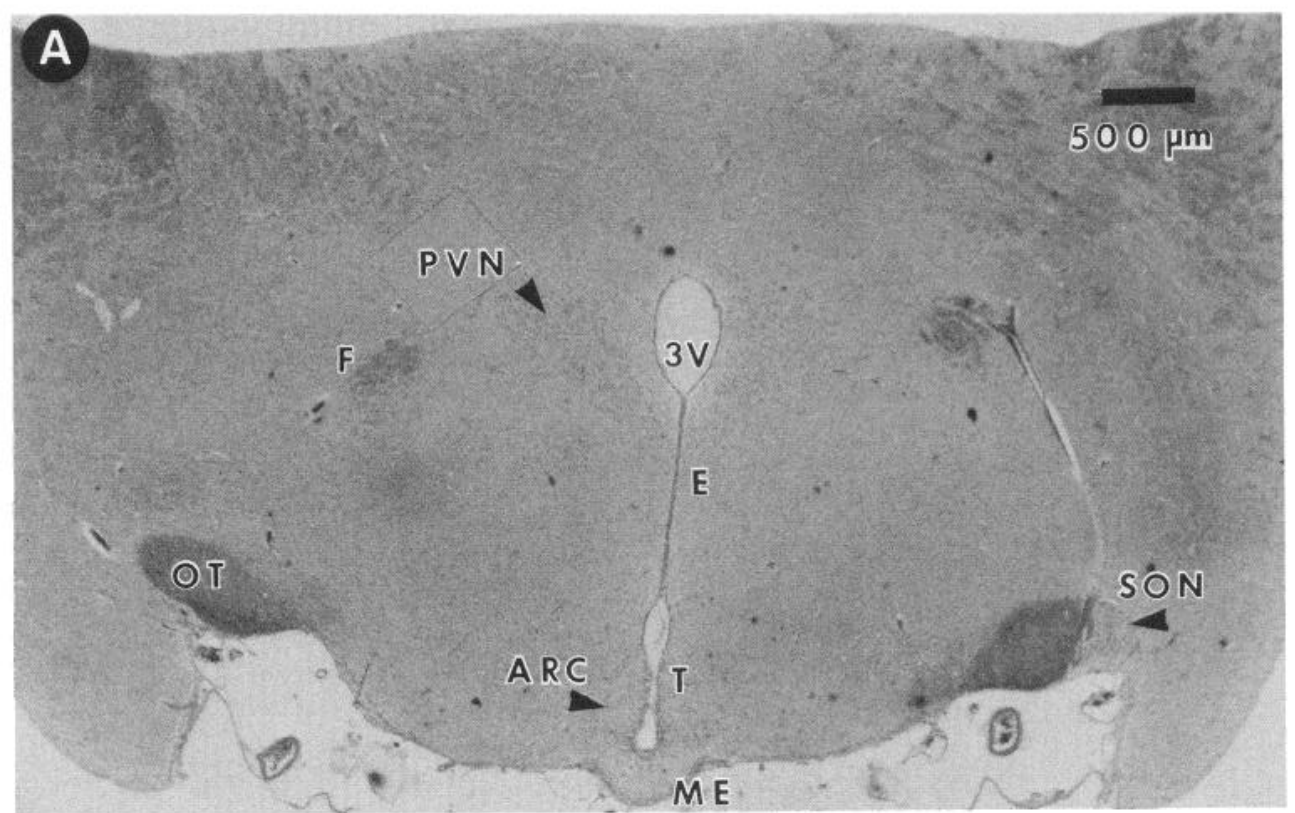

Figure 3. A, Light micrograph of the hypothalamic slice at the level of the median eminence $(M E)$, as cut coronally for electrophysiological experiments. Tissue embedded in paraffin and stained with solochrome cyanine followed by hematoxylin and eosin. Neuroendocrine somata are located in the paraventricular nucleus $(P V N)$ medial to fornix $(F)$, the arcuate nucleus $(A R C)$, and the supraoptic nucleus $(S O N)$ adjacent to optic tract $(O T)$. Common ependyma $(E)$ line the dorsolateral wall of the third ventricle $(3 \mathrm{~V})$. Tanycytes $(T)$ are located more ventrally. $B$, Eponembedded and toluidine blue-stained section of common ependyma $(E)$, which are cuboidal and ciliated. $C$, Tanycyte somata $(T)$ line the ventral third of the third ventricle.
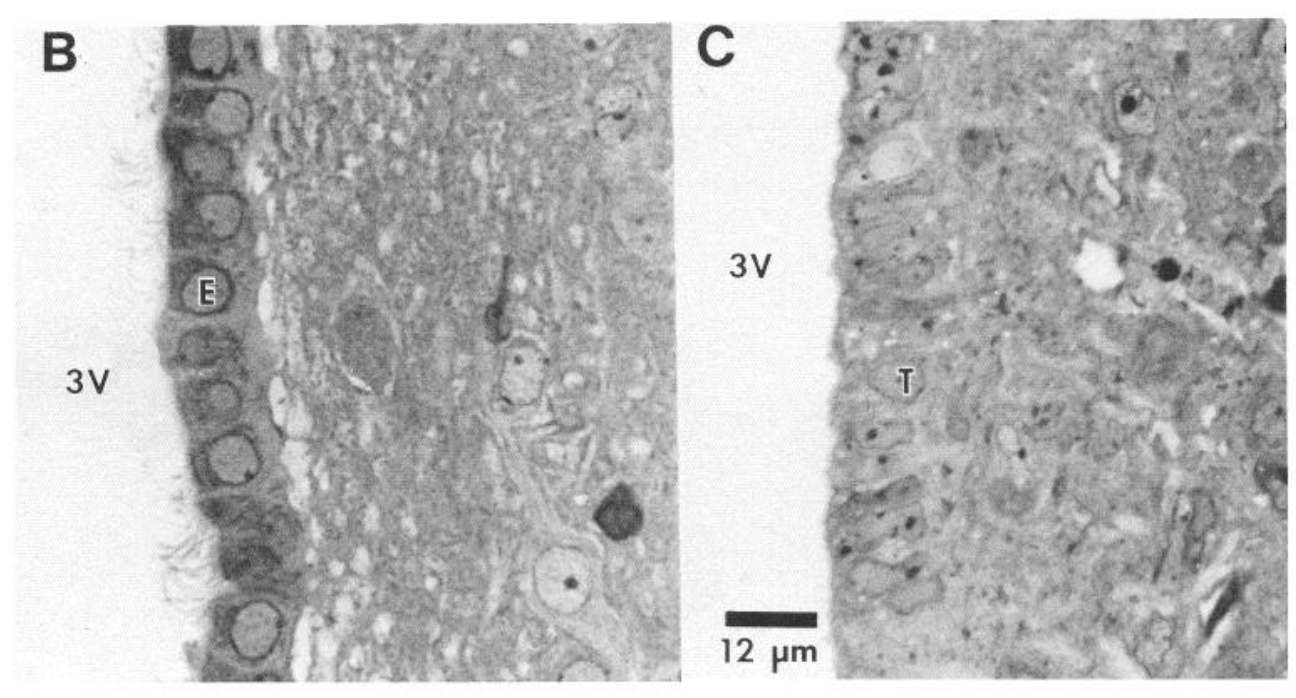

were $30-100 \mathrm{M} \Omega$. Stable cells $\left(V_{m}=-60\right.$ to $\left.-80 \mathrm{mV}\right)$ were injected using $0.1-0.5 \mathrm{nA}$ hyperpolarizing current pulses $(500 \mathrm{msec}$ duration at $1 \mathrm{~Hz}$ ). When $V_{m}$ deteriorated to $-40 \mathrm{mV}$, dye injection was terminated and the microelectrode withdrawn. Slices were fixed in $5 \%$ formaldehyde in $0.1 \mathrm{M}$ sodium cacodylate for $1-2 \mathrm{hr}$ and stored in $0.1 \mathrm{M}$ sodium cacodylate buffer. For sectioning, slices were washed in buffer containing $30 \%$ glucose for $15 \mathrm{~min}$ and then mounted on the microtome stage in $0.1 \%$ agar. Sections $(25-40 \mu \mathrm{m})$ were cut with a freezing microtome, mounted on gelatinized slides, cleared in methyl salicylate, and photographed with a Zeiss Photomicroscope II fitted for epifluorescence with appropriate filters. Sagittal slices were not sectioned but were simply fixed, dehydrated, and cleared.

Uncoupling of gap junctions. Reduction or elimination of intercellular coupling between ependymal cells (i.e., "uncoupling") was attempted using several agents known to uncouple cells in other systems. Sodium proprionate $(100 \mu \mathrm{M})$, which is effective in decreasing dye coupling in CA3 hippocampal neurons (MacVicar and Jahnsen, 1985), was added to the regular superfusate. Alternately, the saline was equilibrated with $100 \% \mathrm{CO}_{2}$ instead of $95 \% \mathrm{O}_{2}-5 \% \mathrm{CO}_{2}$ (Connors et al., 1984). The influence of cytoplasmic acidification via sodium propionate or $\mathrm{CO}_{2}$ was examined by looking for an increased cell $R_{\text {in }}$, which would sugges that the electrotonic spread of current into other cells had been restricted. Current $(1-8 \mathrm{nA})$ was injected into a cell and the resultant voltage response recorded in an attempt to obtain a measurement for total cell
$R_{\text {in }}$ after tissue exposure to the uncoupling agents. During sodium propionate exposure, some cells were injected with Lucifer yellow.

\section{Results}

Morphology

Morphological studies were carried out to better localize homogeneous populations of common ependymal cells and tanycytes lining the third ventricle (Fig. 1), facilitating a comparison of the 2 populations electrophysiologically. These 2 cell types were also examined ultrastructurally for gap junctions to further study the morphological substrate of electrotonic coupling and dye coupling.

SEM. Regional surface variations in the third ventricular wall were observed even at low magnification with SEM (Fig. 2). Rostral to the optic chiasma, the ependymal surface was covered by cilia. More caudally at the level of the median eminence, the surface was ciliated dorsally but smoother ventrally. Closer examination of the dorsal wall revealed a dense nap of cilia covering the ependyma (Fig. 2, area 1). A smoother area more ventrally was covered with microvilli (Fig. 2, area 3). Apical 

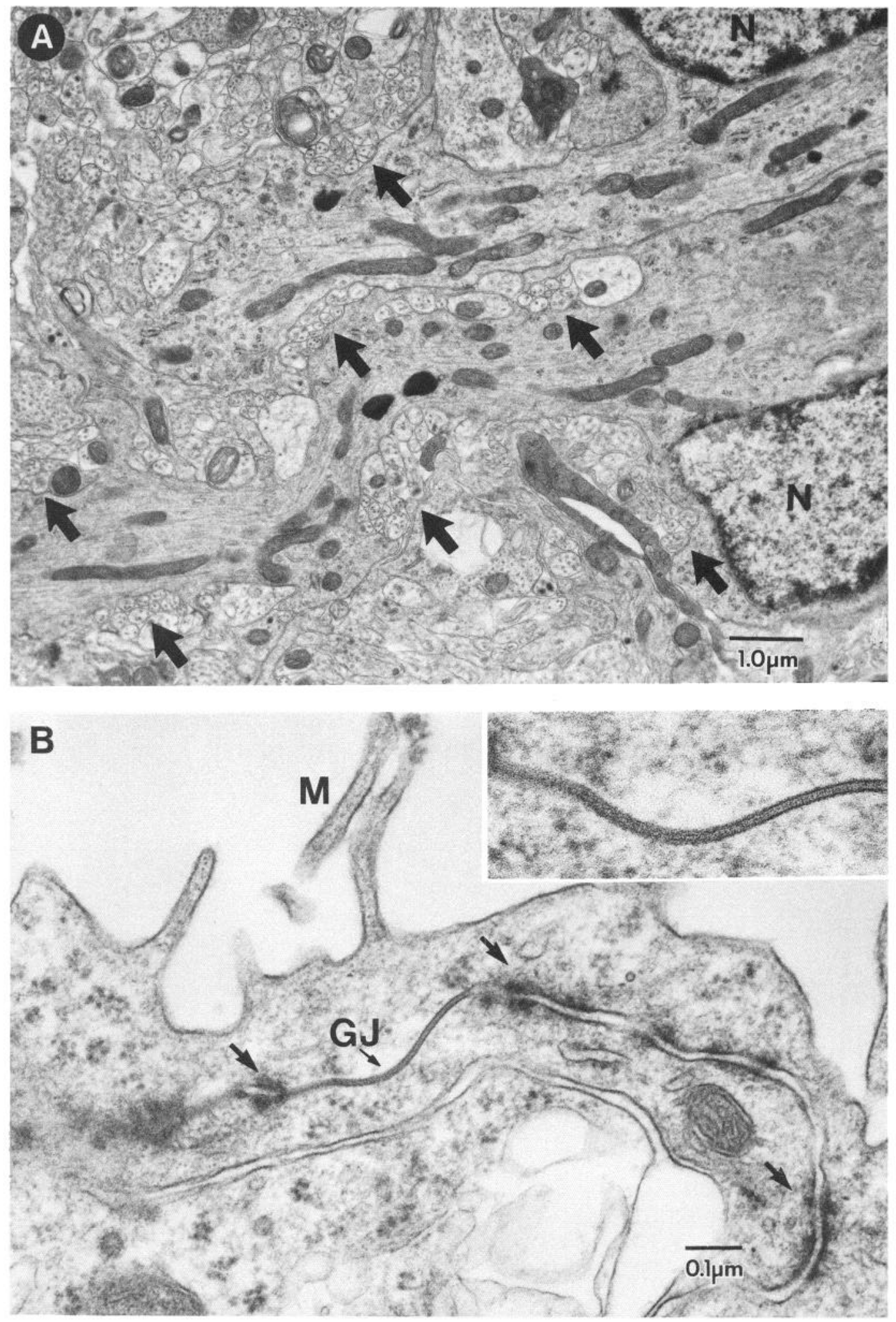

Figure 4. A, Two tanycyte perikarya and their nuclei $(N)$ with basal extensions into underlying neuropil. These processes are closely associated with numerous small-diameter axons (arrows) previously shown to contain neurosecretory peptides (Kozlowski and Coates, 1985). B, Apical processes of adjacent tanycytes display microvilli $(M)$, adherens junctions (arrows), and a gap junction (GJ). Inset, Gap junction at higher magnification. 

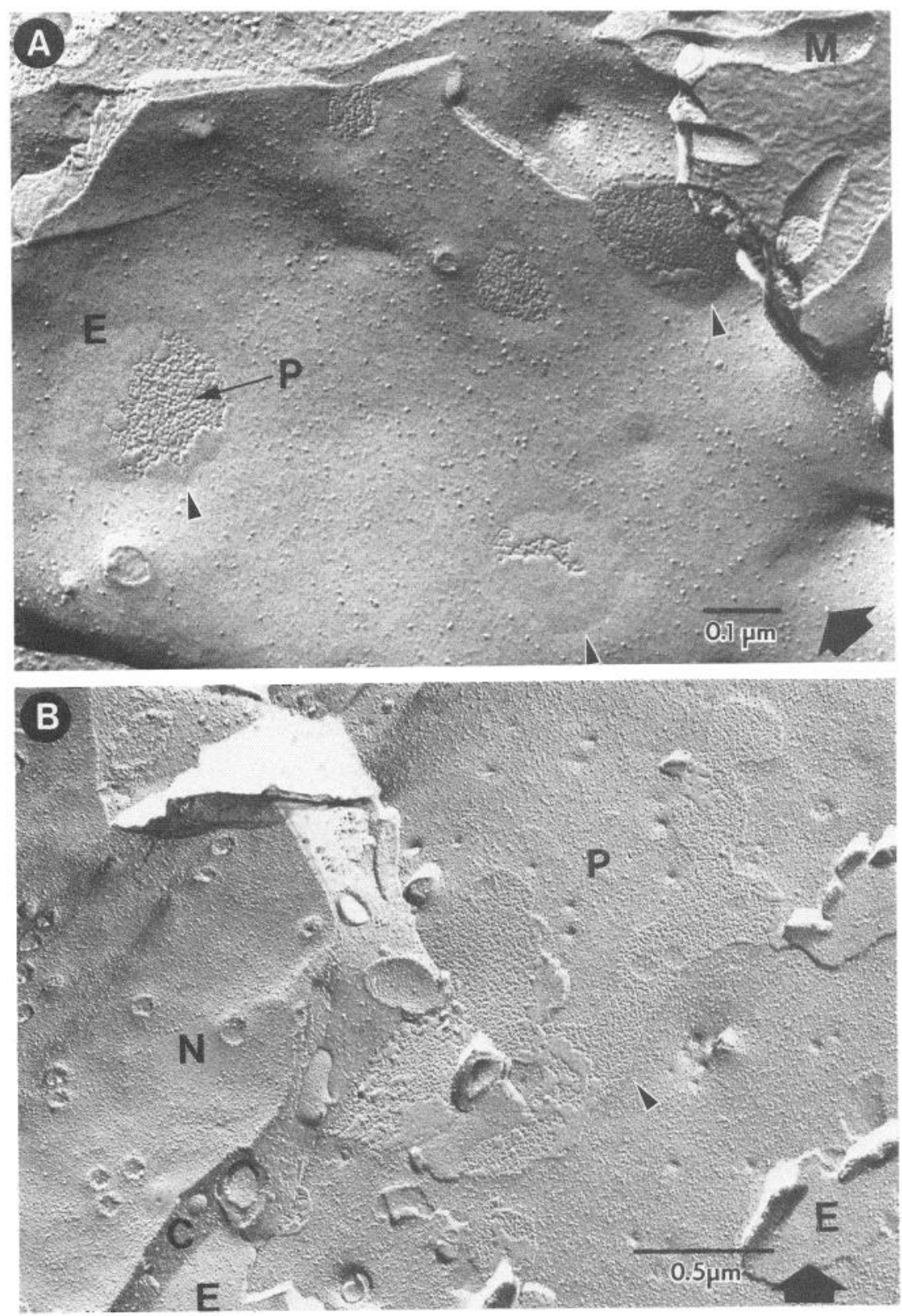

Figure 5. A, Apical portion of common ependyma with microvilli $(M)$ and cilia (not shown). Gap junctions ( $a r-$ rows) are represented as particle aggregates on the membrane's P-face $(P)$ and as indentations on the E-face $(E)$. Large arrow represents direction of platinum shadowing. $B$, Central portion of common ependyma adjacent to the paraventricular nucleus. From the left, the fracture plane follows nuclear membrane $(N)$, cytoplasm $(C)$, E-face membrane $(E)$, and P-face membrane $(P)$. Note the large aggregation of gap junctions (arrow), as well as 2 smaller ovoid aggregates lower in the frame. $C$, Numerous gap junctions (arrowheads) are associated with the membrane of adjacent tanycytes.

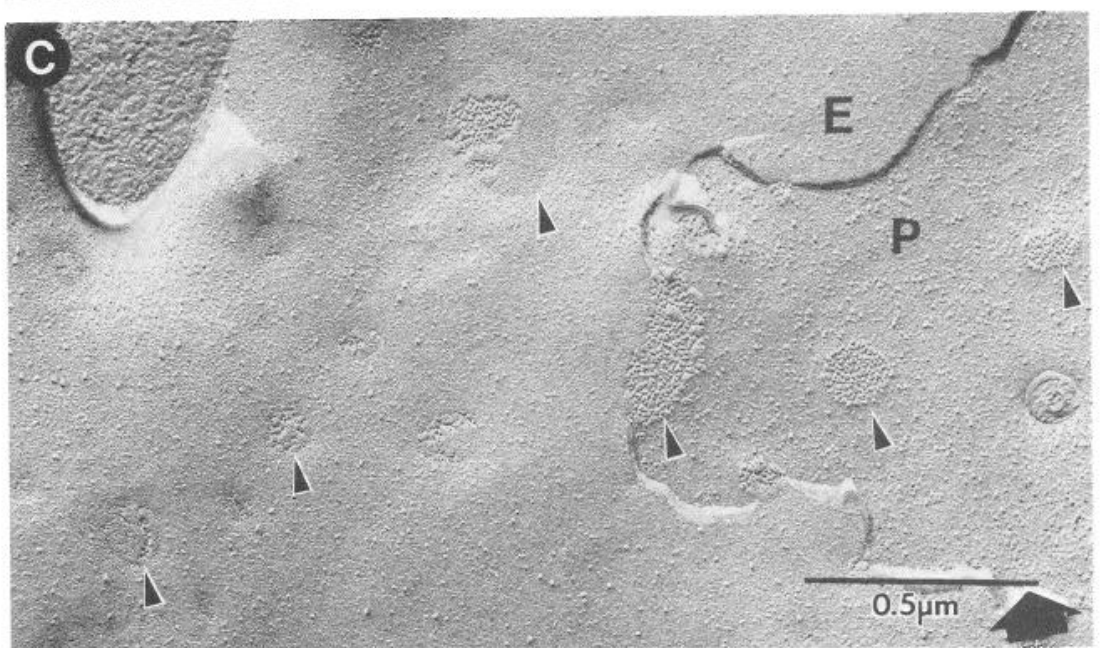


"blebs" (spherical protrusions) were also observed within the infundibular recess. A transitional area containing both cell types was observed approximately midway along the lateral wall (Fig.2, area 2 ). The transition zone was avoided when recording intracellularly from the ependyma.

Thin sections. These helped correlate the location of common ependyma and tanycytes seen at the light microscopical level (Fig. 3A) with surface features seen with SEM (Fig. 2). Common ependyma formed a simple layer of cuboidal cells (Fig. 3B), each about $12 \mu \mathrm{m}$ from base to apex. Tanycyte somata were elongated to about $15 \mu \mathrm{m}$ (Fig. 3C). Basal prolongations coursed through the underlying neuropil (Fig. $4 A$ ), and apical slips extended to the third ventricle, where microvilli were observed (Fig. $4 B$ ). In contrast, the luminal surface of common ependymal cells displayed prominent cilia covering smaller microvilli when viewed with SEM (Fig. 3, area 1). The nuclei of common ependymal cells were round, whereas tanycyte nuclei were ovoid.

In thin section, gap junctions were observed between cells of common ependyma throughout their apical and basal extent (not shown) and between adjacent tanycyte somata or apical processes (Fig. 4B). They exhibited a classic septilaminar appearance with the median cleft continuous with the extracellular space. The narrow gap was sometimes bridged by a spot contact, which is considered a single channel between adjacent cells (Fig. $4 B$, insert).

Freeze fracturing. Freeze fracturing revealed membrane specializations between adjacent ependymal cells. Again, common ependymal cells could be distinguished from tanycytes by the presence of both cilia and microvilli projecting into the lumen of the third ventricle. Gap junctions were identified within plasma membrane as particle aggregates on the protoplasmic surface (P-face) or occasionally as faint depressions on the extracellular surface (E-face). It was difficult to determine if the 2 cell types shared gap junctions in the transition zone because of the difficulty in unequivocally identifying both partners of a cell pair. Freeze-fracture replicas revealed large numbers of gap junctions between adjacent ependymal cells (Fig. 5, $A, B$ ) and between adjacent tanycytes (Fig. $5 C$ ). They usually occurred in ovoid aggregates ranging from a few to several hundred particles. Occasionally, an aggregate formed an extensive array of over 2000 junctions (Fig. $5 B$ ), suggesting strong electrotonic coupling betwecn adjacent cells.

\section{Electrophysiology}

Basic properties. Intracellular recordings of $>5 \mathrm{~min}$ in both coronal and sagittal preparations (Fig. 6A) revealed resting membrane potentials $\left(V_{m}\right)$ of $-79.9 \pm 1.40 \mathrm{mV}(n=30)$ for common ependymal cells and $-79.5 \pm 1.77 \mathrm{mV}(n=46)$ for lanycyles (mean $\pm \mathrm{SD}$ ). The distribution of resting $V_{m}$ values for both cell types is shown in Figure $6 B$. Cells with values less negative than $-77 \mathrm{mV}$ were usually unstable over time and were considered damaged. No stable intracellular recording from common ependyma or tanycytes displayed spontaneous action potentials, spontaneous postsynaptic potentials, or slow changes in $V_{m}$ over time.

Intracellular injection of up to $\pm 8 \mathrm{nA}$ of current caused no detectable voltage deflection (Fig. $6 A$ ). Therefore, we could not establish a relationship between injected current and the voltage response in these cells. From Ohm's law $(V=I R)$, the input resistance $\left(R_{\text {in }}\right)$ of both cell types was approximated to be very low $(\ll 1 \mathrm{M} \Omega$ ). Comparable measurements from glial cells in adjacent neuropil ranged from 2 to $20 \mathrm{M} \Omega$.

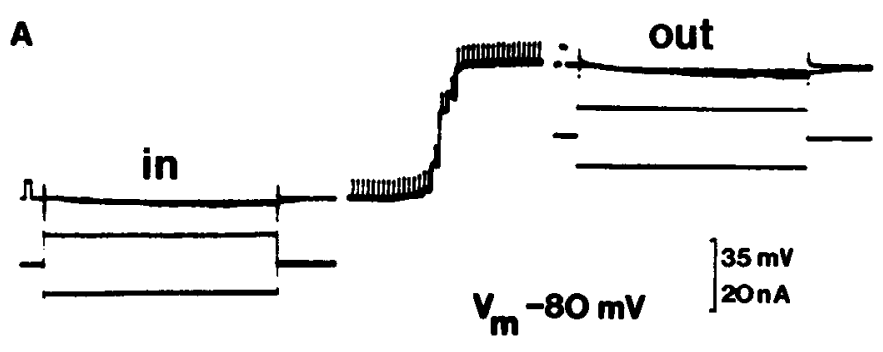

$\mathbf{B}$

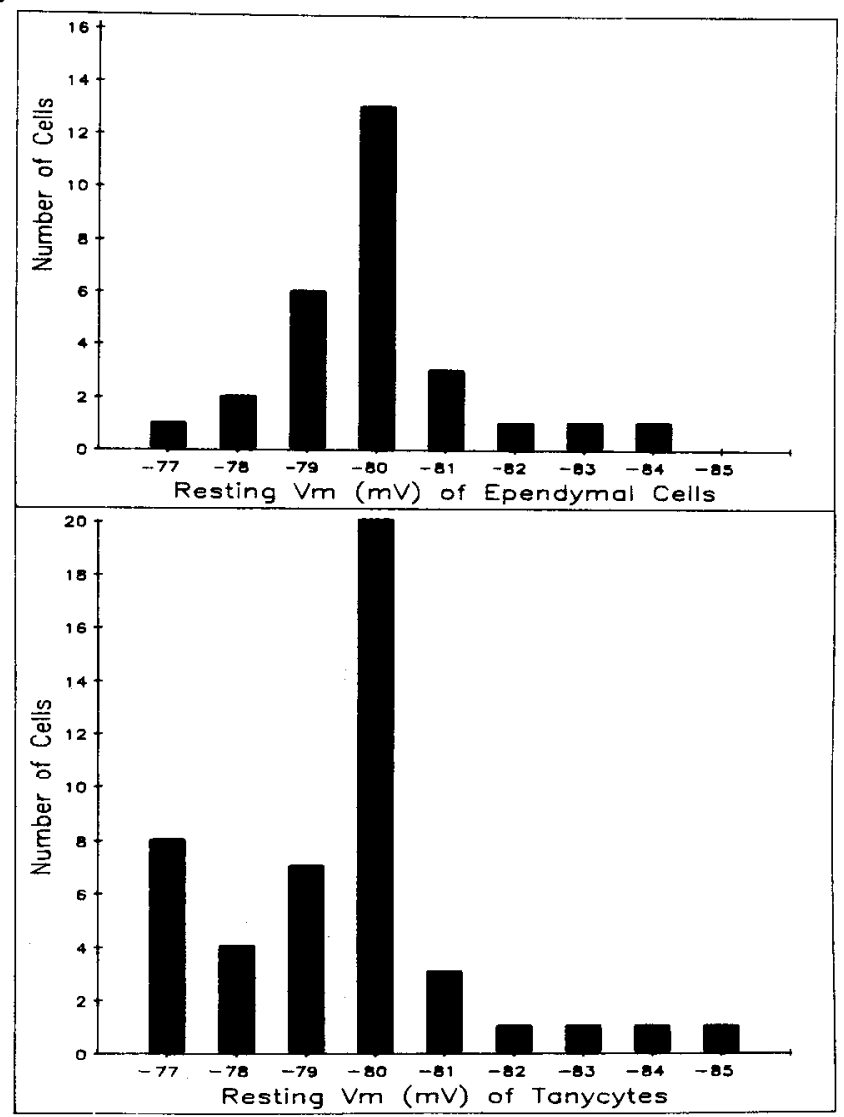

Figure 6. $A$, Intracellular injection of $\pm 8 \mathrm{nA}$ of current into an ependymal cell caused no detectable voltage deflection (left). Withdrawal of the micropipette during calibration pulses (center) reveals a resting membrane potential $\left(V_{m}\right)$ of $-80 \mathrm{mV}$ (right). Calibration pulse, $10 \mathrm{mV}$, 5 msec. $B$, Histogram showing the distribution of resting membrane potentials $\left(V_{m}\right)$ in common ependyma (above) and tanycytes (below). All recordings in regular saline.

The measurement of electrotonic current spread within the ependymal layer was altempted by inserting a 3 м $\mathrm{KCl}$ microelectrode into each of 2 neighboring cells. Current was injected into one cell and the electrotonic potential change was monitored in a second nearby cell. Theoretically, a coupling ratio can be measured as the electrotonic potential change in the nearby cell divided by the electrotonic potential change in the current-injected cell. However, no voltage change could be imposed on the recorded cell or on a second neighboring cell, presumably because injected current was shunted throughout the ependymal layer. The inability to induce voltage responses using current injection meant that slower voltage-sensitive currents, if present, could not be examined. We attempted to alleviate this situation by reducing the coupling between cells (below). 


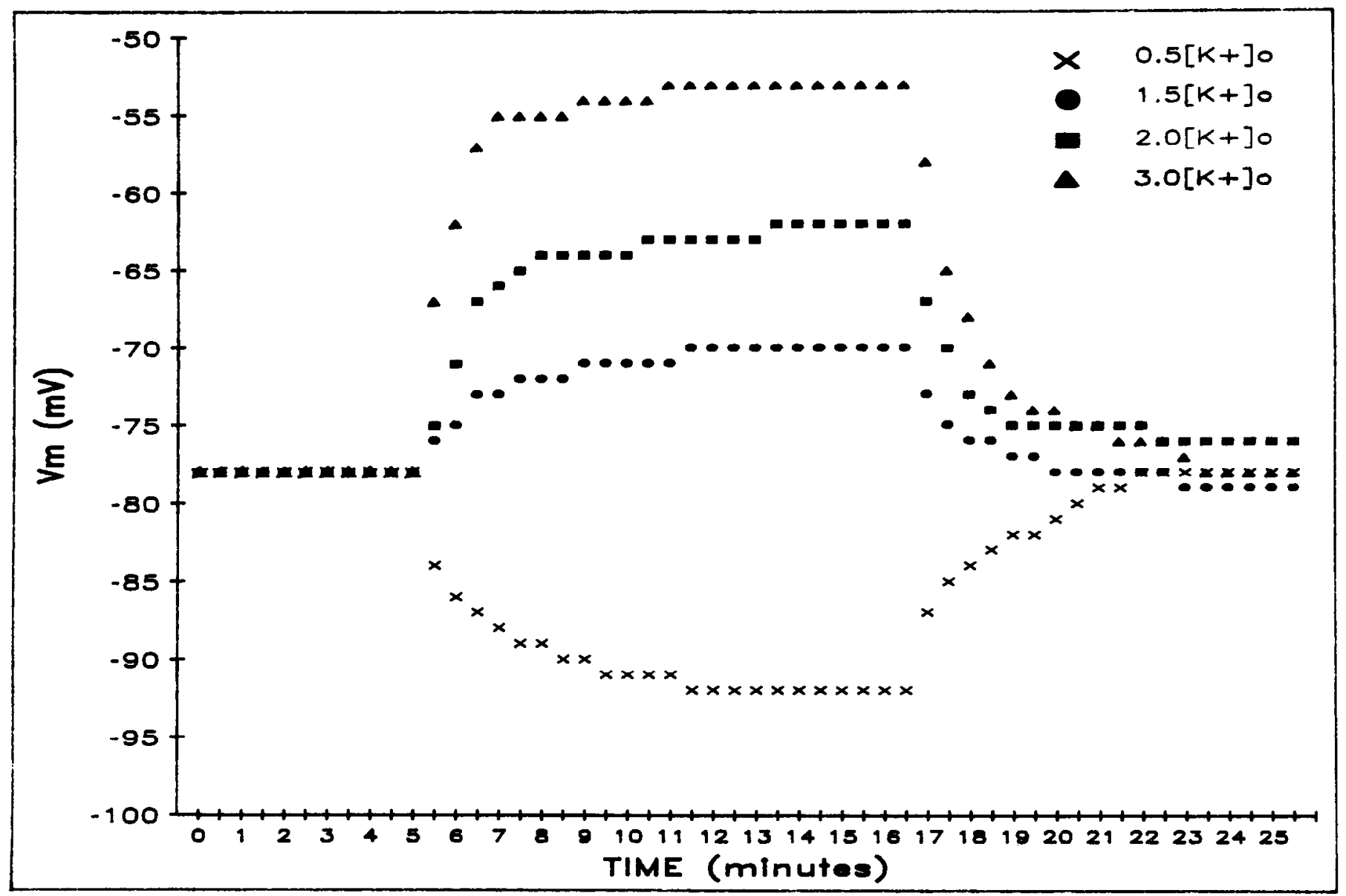

Figure 7. Effects of varying the extracellular $\mathrm{K}^{+}$concentration $\left(\left[\mathrm{K}^{+}\right]_{0}\right)$ on the membrane potential $\left(V_{m}\right)$ over time. Variable $\mathrm{K}^{+}$concentrations were applied at $5 \mathrm{~min}$ and returned to regular saline $\left(\left[\mathrm{K}^{+}\right]=6.24 \mathrm{mM}\right)$ at $16.5 \mathrm{~min}$.

The $V_{m}$ of ependymal cells and tanycytes was found to be sensitive to changes in $\left[\mathrm{K}^{+}\right]_{0}$ such that $V_{m}$ depolarized with increasing $\left[\mathrm{K}^{+}\right]_{0}$ and hyperpolarized with decreasing $\left[\mathrm{K}^{+}\right]_{0}$. These effects were reversible and reproducible, as shown in Figure 7. Theoretically, if the cell membrane was permeable only to $\mathrm{K}^{+}$, the system would come to equilibrium at a new $V_{m}$ following a change in $\left[\mathrm{K}^{+}\right]_{0}$ as determined by the Nernst equation for $\mathrm{K}^{+}$. Graphing $\log \left[\mathrm{K}^{+}\right]_{o}$ against experimental $V_{m}$ values showed that ependymal cells and tanycytes demonstrate a near-Nernstian change in $V_{m}$ in response to increases in $\left[\mathrm{K}^{+}\right]_{0}$ between 3.12 and $18.7 \mathrm{~mm}$ (Fig. 8). The linear slopes were 59 and $53 \mathrm{mV}$, respectively, as compared with $61.4 \mathrm{mV}$ predicted theoretically at $36^{\circ} \mathrm{C}$. Below $3.12 \mathrm{~mm}$, the decrease in $V_{m}$ clearly deviated from the Nernst equation. Ependymal cell and tanycyte values had slopes of 32 and $29 \mathrm{mV}$, respectively, in response to $1 / 4\left[\mathrm{~K}^{+}\right]_{\mathrm{o}}(1.56 \mathrm{~mm})$.

Stimulation of arcuate neurons. To investigate whether an electrophysiological correlate of the synapselike contacts between putative presynaptic neuroendocrine axons and postsynaptic tanycytes could be detceted, hypothalamic neurons in the arcuate nucleus were stimulated while tanycyte $V_{m}$ was monitored. Stimulation of the putative presynaptic cells at $1 \mathrm{~Hz}$ did not elicit any change in the $V_{m}$ of impaled tanycytes, either over a period of milliseconds or seconds.

Dye injections. All successful injections of single cells with Lucifer yellow revealed dye coupling among groups of common ependymal cells ranging from 2 to approximately 70 cells ( $n=$ 26) (Figs. 9, 10B). Among tanycytes, groups ranged from 2 to approximately 48 cells $(n=15)$. Tanycytes were observed in the ventral portion of the third ventricle at the level of the median eminence. They were distinguished by their processes, which arched ventrolaterally towards the median eminence (Fig. $10 \mathrm{~A}$ ). With coupling involving many tanycyte somata, processes contained little dye (not shown).

Ependymal cell injections were morphologically distinct from glial cell injections. Whereas dye-coupled cells of the ependyma were clustered, dye-coupled glial somata were more dispersed (Fig. 10C), forming a sphere of nuclei about the injection site. Like ependymal cells, the resting potentials of glia were consistently around $80 \mathrm{mV}$ in our slice preparations (unpublished observations). Of 42 dye injections in the ependymal cell layer, only one (Fig. 10C) proved to be a glial cell (and so situated outside the ependymal layer). This assured us that our noninjected recordings were indeed from the ependymal layer. In just one case, a dye-coupled aggregate of common ependyma also displayed a few faint glial nuclei (Fig. 10B), an artifact of unknown origin.

Uncoupling of gap junctions. Uncoupling of ependymal cells was attempted using agents known to uncouple cells in other systems. Exposing the ependyma to sodium propionate for over $1 \mathrm{hr}$ in regular saline resulted in no detectable uncoupling. Specifically, intracellular injection of up to $1 \mathrm{nA}$ of current did not 


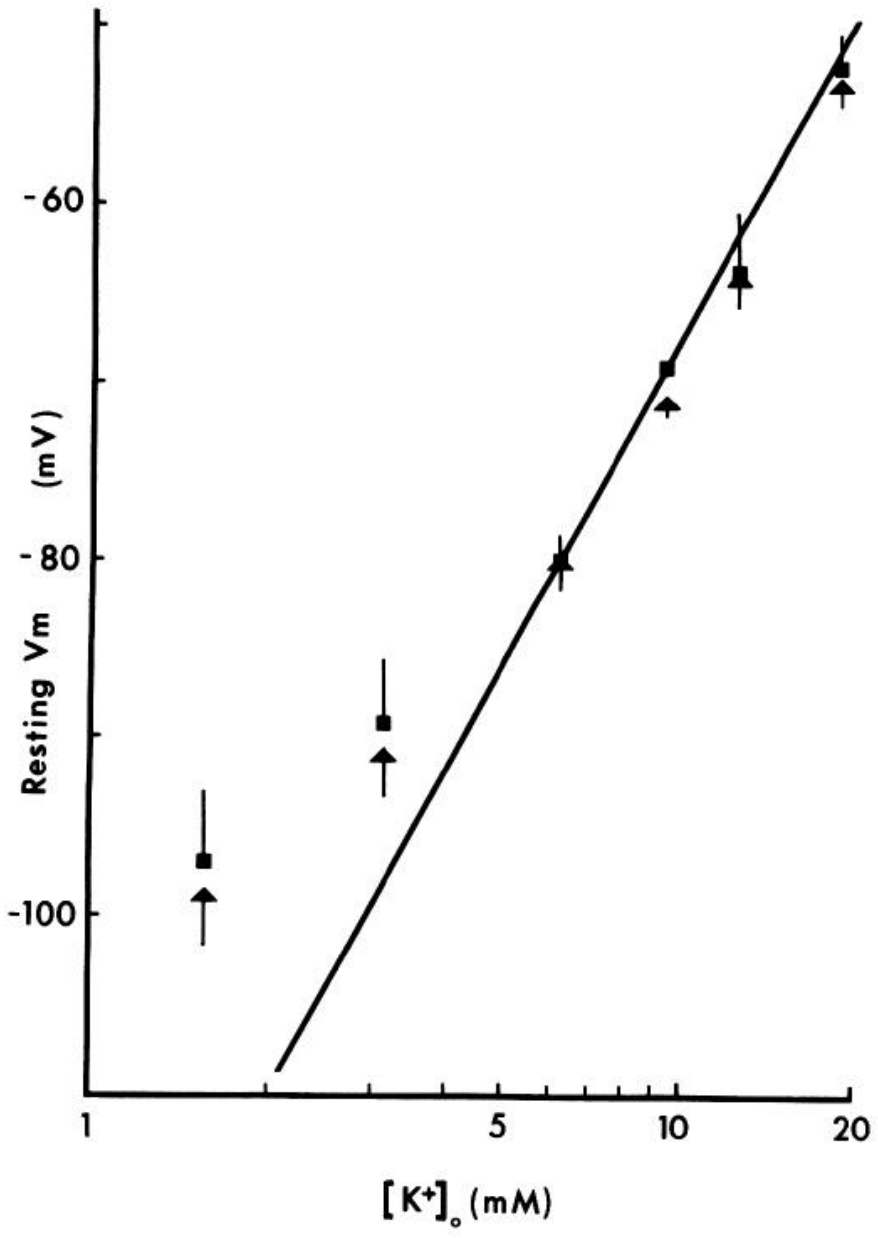

Figure 8. Membrane potential $\left(V_{m}\right)$ of common ependyma and tanycytes as a function of $\left[\mathrm{K}^{+}\right]_{\text {o }}$ plotted on a log scale. Solid line represents the slope of $61.4 \mathrm{mV}$ derived from the Nernst equation at $36^{\circ} \mathrm{C}$. For each point, $n=3-10$ cells. Bars represent SD.

elicit a $V_{m}$ change that would imply an increase in total cell $R_{\text {in }}$ brought about by a reduction in electrotonic coupling. In support of this, dye injection of cells exposed to sodium propionate for $0.5-4 \mathrm{hr}$ showed a persistence of dye coupling in ependymal cells ( $2-12$ coupled cells, $n=7)$ and tanycytes ( $2-8$ coupled cells, $n=3$ ). No obvious reduction in the extent of dye coupling compared with controls (above) could be inferred.

Attempts to uncouple ependymal cells with $100 \% \mathrm{CO}_{2}$-equilibrated saline were inconclusive because intracellular impalements were consistently and completely lost within one minute of $\mathrm{CO}_{2}$ exposure.

\section{Discussion}

\section{Morphology}

The spatial distribution of common ependymal cells and tanycytes observed in this study was consistent with that reported in the rat by other investigators (see introductory remarks) as observed with light microscopy, TEM, and SEM. Within the lining of the third ventricle at the level of the median eminence, cuboidal ependymal cells were situated dorsally and tanycytes ventrally. Both were found midway along the lateral wall. For intracellular recordings, this transition zone was avoided to ensure that data were exclusively from either common ependyma or from tanycytes.
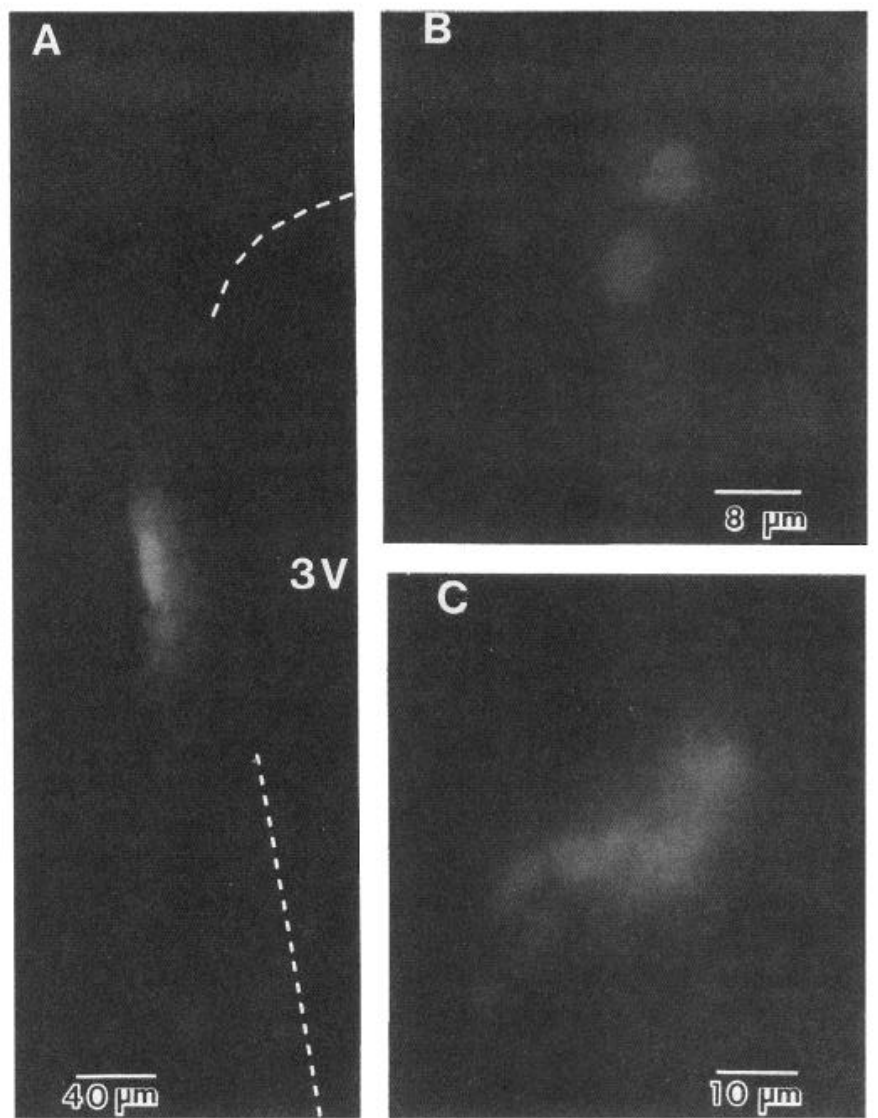

Figure 9. Dye coupling resulting from the injection of Lucifer yellow into a single common ependymal cell. The small diameter and close apposition of these cells made them difficult to resolve in coronal sections. $A$, Coupling among approximately 25 cells in the dorsolateral wall of the third ventricle ( $3 \mathrm{~V})$. A second serial section (not shown) showed 10 more cells of the coupled aggregate. $B$, Ensemble of 4 or 5 common ependymal cells. Note the dye's affinity for nuclei. $C$, Another ensemble of about 12 coupled cells.

Our observations of intercellular junctions in thin section and in freeze-fracture specimens were in general agreement with those of other investigators (Brightman and Palay, 1963; Farquhar and Palade, 1963; Brightman et al., 1975; Brawer and Walsh, 1982; Monroe and Holmes, 1982). We observed gap junctions between homologous cell types, although our sample was not extensive enough to confirm if neighboring common ependymal cells and tanycytes in the transition zone were so connected. The visualization of extensive gap junction arrays between ependymal cells provides a morphological substrate for the dye coupling and explains several electrophysiological findings noted below.

\section{Electrophysiology}

Cells of the ependyma in rat demonstrated several electrophysiological properties characteristic of glial cells. Low resting $V_{m}$ of rat ependymal cells (approx. $-80 \mathrm{mV}$ ) approximated that of glial, which was between -78 and $-82 \mathrm{mV}$ as measured in our slices (unpublished results). Similar to glia, rat ependymal cells demonstrated neither electrical excitability nor spontaneous or evoked synaptic potentials. Low cell $R_{\text {in }}$ is also characteristic of glia (Somjen, 1975, 1979).

The resting $V_{m}$ values of near $-80 \mathrm{mV}$ in both common ependymal cells and tanycytes can be compared with the few 

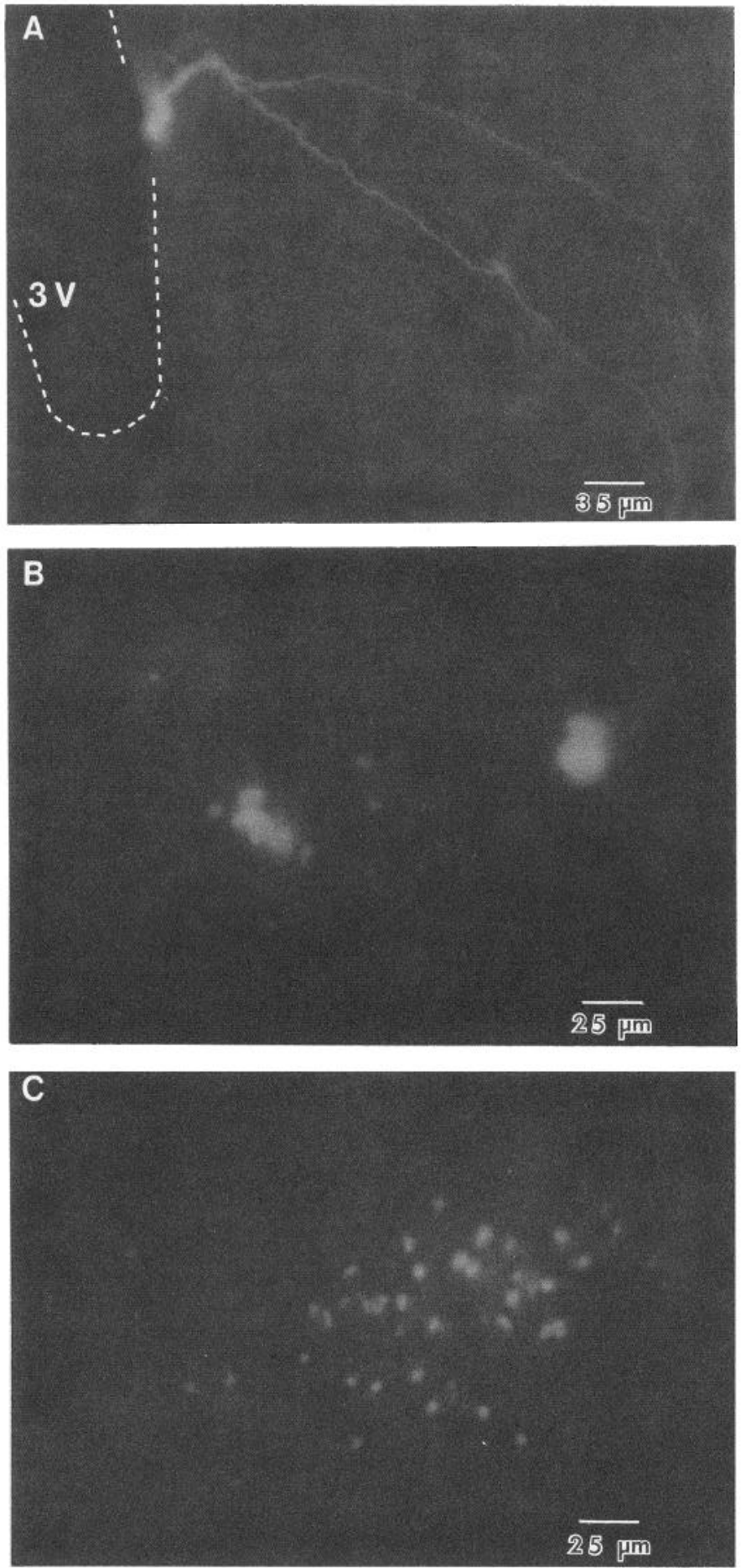

Figure 10. A, Dye coupling between 2 adjacent tanycytes in a coronal slice. Each process arcs ventrolaterally towards median eminence. $B$, Two dye-coupled ensembles of common ependyma in a sagittal slice, each resulting from a single injection of Lucifer yellow. One aggregate (right) is out of the focal plane. The other (left) represents the one fill where a few glial nuclei were artifactually filled. These are peripheral to the closely-spaced ependymal cells. $C$, An aggregate of dye-coupled glia resulting from a single cell injection. The dye's affinity for nuclei obscures the glial processes which transport the dye and are electrotonically linked by gap junctions. Note the clear difference between this glial ensemble and the ependymal ensembles. other electrophysiological studies of the ependyma. Hild et al. (1965) recorded resting $V_{m}$ between -40 and $-60 \mathrm{mV}$ in cultured rat ependymal cells. This low range was derived from impalements lasting only about $1 \mathrm{~min}$, so penetration damage may have caused some depolarization. Similar to our results, Chan and Nicholson (1986) observed a mean resting $V_{m}$ of -78 $\pm 1.4 \mathrm{mV}$ in cerebellar ependyma of turtle, while Connors and Ransom (1987) found a mean value of $-90 \pm 5.3 \mathrm{mV}$ in cortical ependyma of turtle. Assuming $\mathrm{K}^{+}$is the predominant ion determining the resting $V_{m}$ of ependymal cells as discussed below, the difference is explained by the lower $\left[\mathrm{K}^{+}\right]_{\mathrm{o}}$ of the latter study (i.e., $2.6 \mathrm{~mm}$ ). Indeed, as seen from Figure 8 , our $V_{m}$ value extrapolated to $\left[\mathrm{K}^{+}\right]_{0}=2.6 \mathrm{~mm}$ is between -90 and $-95 \mathrm{mV}$.

Regarding cell $R_{\text {in }}$, Hild et al. (1965) reported a value between 0.20 and $0.35 \mathrm{M} \Omega$ for cultured rat ependymal cells. This is lower than that observed by Chan and Nicholson (1986) in turtle slices $(3.9 \pm 0.5 \mathrm{M} \Omega)$, possibly because the cultured cells were more strongly coupled or because the cells were not well impaled. In the present study, $R_{\text {in }}$ was estimated to be $\ll 1 \mathrm{M} \Omega$ even though cells were stable and of high resting potential. An exact value could not be obtained because even low-resistance microelectrodes (15-25 M $\Omega$ ) that could hold stable cells could not pass enough current to elicit a measurable voltage change. Similarly, Connors and Ransom (1987) could not accurately measure $R_{\text {in }}$ of turtle ependymal cells because of bridge-balancing difficulties caused by a fast membrane time constant and low cell $R_{\text {in }}$.

\section{Extracellular $\mathrm{K}^{+}$effects}

Both ependymal cells and tanycytes demonstrated a nearNernstian dependance of membrane potential on $\log \left[\mathrm{K}^{+}\right]_{0}$, where $\left[\mathrm{K}^{+}\right]_{0}$ ranged from 3 to $19 \mathrm{~mm}$. Their respective slopes of 59 and $53 \mathrm{mV}$ in response to a 3 -fold increase in $\left[\mathrm{K}^{+}\right]_{0}$ approximates the theoretical slope of $61.4 \mathrm{mV}$ at $36^{\circ} \mathrm{C}$ as predicted by the Nernst equation. These results are similar to those reported by Connors and Ransom (1987), who found a slope of $54 \mathrm{mV}$ with a 10 -fold increase in $\left[\mathrm{K}^{+}\right]_{\mathrm{o}}$ (theoretical $=59 \mathrm{mV}$ at $24^{\circ} \mathrm{C}$ ). At lower $\left[\mathrm{K}^{+}\right]_{\mathrm{o}}$ levels, our $V_{m}$ values deviated from a linear dependence on $\log \left[\mathrm{K}^{+}\right]_{\mathrm{o}}$, as observed in some neurons, but usually not in glia or in turtle ependyma. At higher $\left[\mathrm{K}^{+}\right]_{0}$ levels, the linearity of the voltage response indicated that $\mathrm{K}^{+}$is the predominant ion determining $V_{m}$. As such, rat ependymal cells behave like glial cells with respect to increases in $\left[\mathrm{K}^{+}\right]_{0}$.

\section{Stimulation of arcuate neurons}

We electrically stimulated arcuate neurons and looked for a postsynaptic change in $V_{m}$ recorded at the tanycyte soma. Although a synchronized excitatory or inhibitory input to many members of a coupled network might lead to a detectable change in $V_{m}$, no response was observed. Thus, we did not detect a physiological correlate of the putative synapses observed ultrastructurally between arcuate neurons and the tanycyte network. Possibly the focal stimulation did not activate enough afferent fibers to alter the resting $V_{m}$ of the strongly coupled network. Alternately, coupled tanycyte processes may have shunted current from the site of recording.

\section{Electrotonic coupling}

As observed in freeze-fracture specimens, ependymal cells are extensively interconnected by gap junctions. These junctions provide a low-resistance pathway for the passage of current between cells. Since current is injected into the cell to measure total cell $R_{\text {in }}$, it was correctly predicted that the presence of 
extensive gap junctions should shunt current to other cells, resulting in a low $R_{\text {in }}$ value. Attempts to confirm the presence of electrical coupling by simultaneously recording from ? neighboring cells was unsuccessful for the same reason: Injected current spread electrotonically throughout the coupled cell network without eliciting a detectable change in $V_{m}$. Presumably with a large enough current pulse, a response could have been measured, but the micropipettes would not pass more than several nanoamps without noise arising from the electrode impedance.

Intracellular dye injections of Lucifer yellow into single ependymal cells confirmed the presence of widespread coupling, both among common ependymal cells and among tanycyte cell bodies. In addition, tanycyte basal processes appeared to be coupled to each other, but further examples are needed to confirm this. Filling was confined to the ependymal layer, i.e., there was no leakage into the adjacent neuropil as expected if dye was flowing cxtracellularly (Andrew ct al., 1982). The resolution of single cells is poor when dye-coupled aggregates are viewed coronally because the dye passes to many cells that are small in diameter and densely packed. Resolution is better when an intact sheet of cells is viewed as a monolayer in sagittal slices. The extensive dye coupling, the large numbers of gap junctions, and the very low input resistances demonstrate that both the common ependymal cell population and the tanycyle population are strongly coupled networks.

Extracellular application of sodium propionate did not affect coupling based on both the persistence of dye coupling and the maintenance of low $R_{\text {in }}$. This suggests that the ependyma are either less sensitive to reductions in intracellular $\mathrm{pH}$ or so extensively coupled that a significant reduction is not detectable with our techniques.

Connors and Ransom (1987) demonstrated that dye coupling could be abolished by increasing the concentration of ambient $\mathrm{CO}_{2}$ and, therefore, that ependymal gap junctions in turtle cortex were sensitive to changes in internal pH. Our trials in $100 \%$ $\mathrm{CO}_{2}$-equilibrated saline were inconclusive. Even the most stable impalements were consistently lost within a minute of exposure to $\mathrm{CO}_{2}$, and measurements during early $\mathrm{CO}_{2}$ exposure showed no increase in cell $R_{\text {in }}$.

\section{Functional significance of a strongly coupled ependymal network}

Why does the ependyma in the rat form such a tightly coupled syncytium? In excitable tissues, gap junctions transfer current rapidly among cells for the synchronization of activity (Dudek et al., 1983; Spray and Bennett, 1985). Since it is clear that rat ependymal cells do not normally fire action potentials, a synchronizing mechanism is unnecessary. Ependymal cells do demonstrate metachronic beating of cilia (Scott et al., 1974), possibly mediated by coupling, but this cannot explain why tanycytes (which lack cilia) are also tightly coupled.

This study shows that rat ependymal cells possess a number of characteristics typical of glial cells (Somjen, 1975, 1979). Common ependymal cells and tanycytes possess a high negative resting $V_{m}$, display a very low cell $R_{\text {in }}$, and respond to extracellular $\mathrm{K}^{+}$levels in a near-Nernstian fashion. They are intimately associated with neuronal processes and display dye coupling mediated by an extensive array of gap junctions. These findings suggest that the ependyma, like glia, may function to spatially buffer extracellular K+ (Somjen, 1975, 1979). Newman (1986, 1987) demonstrated that retinal astrocytes (Muller cells) possess a high $\mathrm{K}^{+}$conductance in their endfeet adjacent to vit-

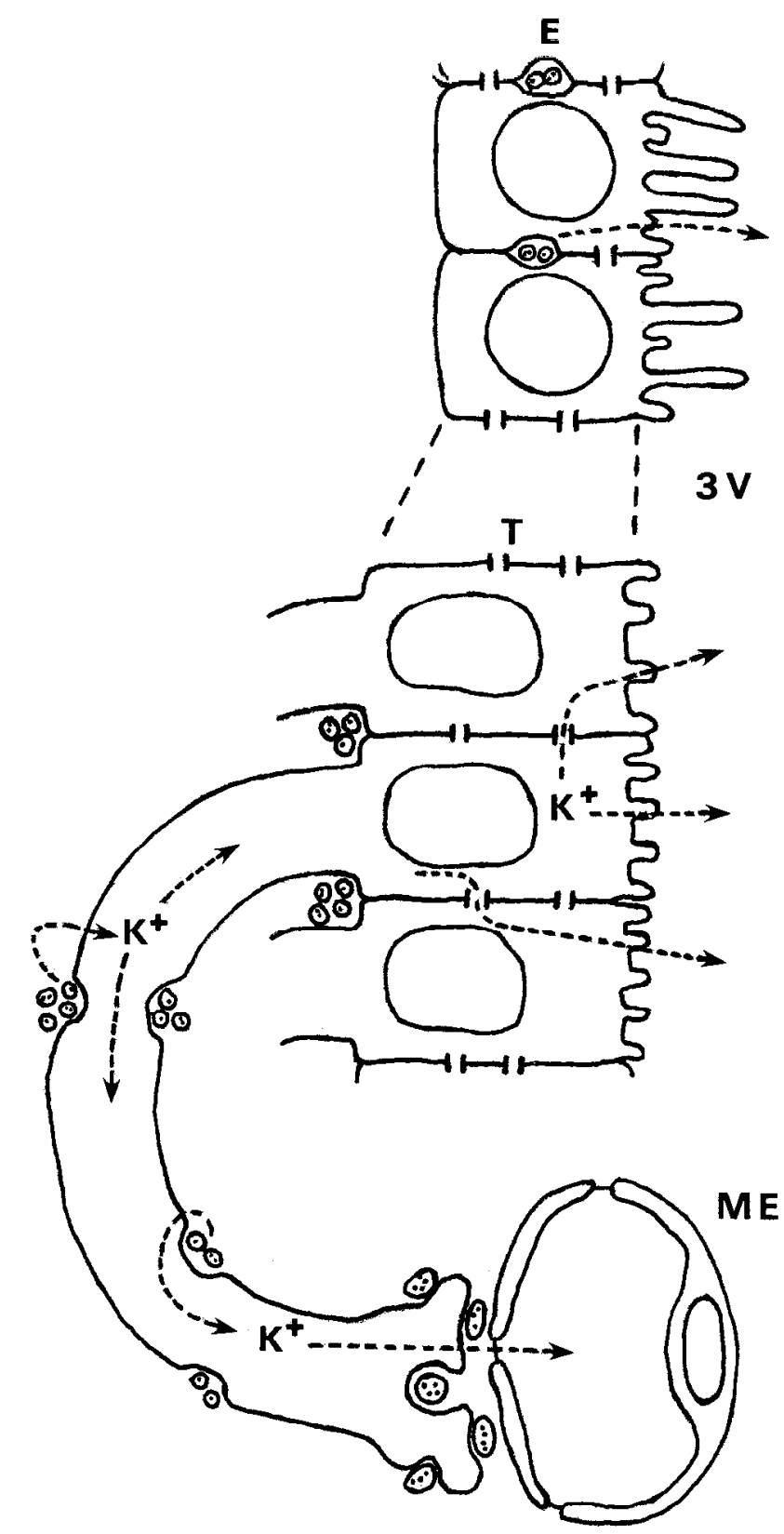

Figure 11. Hypothetical scheme whereby common ependyma $(E)$ and tanycytes $(T)$ could act as conduits that siphon $\mathrm{K}^{+}$(arrows) from basal hypothalamus. Discharging neuroendocrine axons (circles) release $\mathrm{K}^{+}$, which is taken up by ependyma (above) or tanycyte processes (below). The $\mathrm{K}^{+}$is passively shunted to areas of lower $\mathrm{K}^{+}$concentration, specifically into other coupled cells and the third ventricle $(3 V)$. Closer to median eminence $(M E), \mathrm{K}^{+}$is shunted to the capillary network. Extensive coupling and a putative high $\mathrm{K}^{+}$conductance at the tanycyte somata would cause a low $R_{\text {in }}$ value.

reous humor in species lacking a well-vascularized retina. In this case, $\mathrm{K}^{+}$is siphoned from the soma out the endfeet and into vitreous. Connors and Ransom (1987) suggest that turtle ependymal cells may possess a high $\mathrm{K}^{+}$conductance in their cell bodies and propose a siphoning mechanism from endfeet to cell bodies (and so into CSF). Mammalian tanycytes may have a similar function (Fig. 11), shunting $\mathrm{K}^{+}$from the discharging neuroendocrine axons to the ventricular CSF. In the region of median eminence, the processes enwrapping discharging neurons shunt $\mathrm{K}^{+}$to endfeet abutting capillaries. The coupled epen- 
dymal network would facilitate $\mathrm{K}^{+}$diffusion. In this manner, tanycytes could rapidly and efficiently remove accumulated $\mathrm{K}^{+}$ from the extracellular space of basal hypothalamus and so maintain normal neuronal function.

In the neurohypophysis, specialized glia (pituicytes) retract from around neuroendocrine terminals during periods of increased hormone release (Tweedle and Hatton, 1982). The retraction is thought to lead to higher [ $\left.\mathrm{K}^{\dagger}\right]$ levels, promoling axon terminal excitability. Similarly, Kozlowski and Coates (1985) have hypothesized that tanycyte processes enwrapping tuberoinfundibular endocrine neurons may also retract during increased axonal discharge. Thus, the possibility exists that tanycytes not only function passively as $\mathrm{K}^{+}$siphons but, by enwrapping or unwrapping axons, may influence the excitability of mammalian neuroendocrine cells.

\section{References}

Andrew, R. D., C. P. Taylor, R. W. Snow, and F. E. Dudek (1982) Coupling in rat hippocampal slices: Dye transfer between CAl pyramidal cells. Brain Res. Bull. 8: 211-222.

Brawer, J. R., and R. J. Walsh (1982) Response of tanycytes to aging in the median eminence of the rat. Am. J. Anat. 163: 247-256.

Brightman, N. W., and S. L. Palay (1963) The fine structure of the ependyma of the brain of the rat. J. Cell Biol. 19: 415-439.

Brightman, N. W., L. Prescott, and T. S. Reese (1975) Intercellular junctions of special ependyma. In Brain-Endocrine Interaction. II. The Ventricular System in Neuroendocrine Mechanisms, K. M. Knigge, ed., pp. 146-165, Karger, Basel.

Bruni, J. E., M. R. Delbigio, and R. E. Clattenburg (1985) Ependyma: Normal and pathological. A review of the literature. Brain Res. Rev. 9: $1-19$.

Card, J. P., and R. Y. Moore (1985) Axo-glial contacts in the median eminence of the rat. Ultrastructural and immunohistochemical observations. Anat. Rec. 211: 33A.

Chan, C. Y., and C. Nicholson (1986) Responses of ependymal cells to quasi-steady state electric fields. Soc. Neurosci. Abstr. 12: 170.

Connors, B. W., and B. R. Ransom (1987) Electrophysiological properties of ependymal cells (radial glia) in dorsal cortex of the turtle Pseudemys scripta. J. Physiol. (Lond.) 385: 287-306.

Connors, B. W., L. S. Bernardo, and D. A. Prince (1984) Carbon dioxide sensitivity of dye coupling among glia and neurons of the neocortex. J. Neurosci. 5: 1324-1330.

Dudek, F. E., R. D. Andrew, B. A. MacVicar, R. W. Snow, and C. P. Taylor (1983) Recent evidence for and possible significance of gap junctional and electrotonic synapses in the mammalian brain. In Basic Mechanisms of Neuronal Hyperexcitability, H. H. Jasper and N. M. van Gelder, eds., pp. 31-73, Liss, New York.

Farquhar, M. G., and G. E. Palade (1963) Junctional complexes in various epithelia. J. Cell Biol. 17: 375-412.
Flament=Durand, J., and J. P. Brion (1985) Tāñyeytes: Morphology and functions. A review. Int. Rev, Cylol, 96:121-155.

Fleischhauer, K. (1972) Ependyma and subependymal layer. In The Structure and Function of Nervous Tissue, G. H. Bourne, ed., pp. 146. Academic, New York.

Hild, W., T. Takenaka, and F. Walker (1965) Electrophysiological properties of ependymal cells from the mammalian brain in tissue culture. Exp. Neurol. 11: 493-501.

Jarvis, C. R., and R. D. Andrew (1987) Electrophysiology and morphology of ependymal cells and tanycytes in the rat hypothalamus. Soc. Neurosci. Abstr. 13: 1206.

Kobayashi, H., H. Matsui, and S. Ishii (1970) Functional electron microscopy of the hypothalamic median eminence. Int. Rev. Cytol. 29: $281-381$.

Kozlowski, G. P., and P. W. Coates (1985) Structural and functionai inter-relationships between the LHRH neurosecretory system and ependyma. In Neurosecretion and the Biology of Neuropeptides, $\mathrm{H}$. Kobayashi, H. A. Bern, and A. Urano, eds., pp. 165-171, SpringerVerlag, Berlin.

MacVicar, B. A., and H. Jahnsen (1985) Uncoupling of CA3 pyramidal neurons by propionate. Brain Res. 330: 141-145.

Monroe, B. G., and E. M. Holmes (1982) The freeze-fractured median eminence. I. Development of intercellular junctions in the ependyma of the third ventricle of the rat. Cell Tissue Res. 222: 389-408.

Newman, E. A. (1986) High potassium conductance in astrocyte endfeet. Science 233: 453-454.

Newman, E. A. (1987) Regulation of potassium levels by Muller cells in the vertebrate retina. Can. J. Physiol. Pharmacol. 65: 1028-1032.

Peters, A., S. L. Palay, and H. de Webster (1976) The ependyma. In The Fine Structure of the Nervous System: The Neurons and Supporting Cells, A. Peters, ed., Saunders, Philadelphia.

Pilgrim, C. II. (1978) Transport function of hypothalamic tanycyte ependyma: How good is the evidence? Neuroscience 3: 277-283.

Scott, D. E., G. P. Kozlowski, and M. N. Sheridan (1974) Scanning electron microscopy in the ultrastructural analysis of the mammalian cerebral ventricular system. Int. Rev. Cytol. 37: 349-389.

Shivers, R. R., and M. W. Brightman (1976) Trans-glial channels of crayfish ventral nerve roots in freeze-fracture. J. Comp. Neurol. 167: $1-26$.

Somjen, G. F. (1975) Electrophysiology of neuroglia. Annu. Rev. Physiol. 37: 163-190.

Somjen, G. F. (1979) Extracellular potassium in the mammalian central nervous system. Annu. Rev. Physiol. 41: 159-177.

Spray, D. C., and M. V. L. Bennett (1985) Physiology and pharmacology of gap junctions. Annu. Rev. Physiol. 47: 281-303.

Stewart, W. W. (1978) Functional connections between cclls as revealed by dye-coupling with a highly fluorescent naphthalimide tracer. Cell 14: 741-759.

Tweedle, C. D., and G. I. Hatton (1982) Magnocellular neuropeptidergic terminals in neurohypophysis: Rapid glial release of enclosed axons during parturition. Brain Res. Bull. 8: 205-209. 